\title{
Star architecture projects. The assessment of spatial economic effects by means of a spatial incidence analysis
}

\section{Stararchitekturprojekte. Die Bewertung raumökonomischer Effekte durch die Anwendung der räumlichen Inzidenzanalyse}

https://doi.org/10.2478/rara-2020-0029

Eingegangen: 31. Januar 2020, Angenommen: 29. September 2020

\begin{abstract}
Following the inauguration of the Guggenheim Museum Bilbao, designed by the star architect Frank Gehry, numerous cities have developed star architecture projects that try to emulate the 'Bilbao Effect' in the hope of triggering positive impacts for tourism and socio-economic development. However, as many projects do not achieve the set goals, their role as catalysts for urban development is debatable. We argue that the temporal and spatial economic dimension of the effects of star architecture projects - which are hardly discussed in existing literature is crucial to assess the contribution of such projects for urban regeneration. The Kunsthaus Graz in Austria serves as a case study where we apply and modify the approach of the 'spatial incidence analysis' to assess the socioeconomic and intertemporal effects of a publicly funded, star architecture project. The spatial incidence analysis is closely related to the cost-benefit analysis, but takes into consideration wider aspects of the spatial distribution and intertemporal development of three dimensions of effects: payment flows, goods and services, and utility. We identify the following key findings by applying a combination of quantitative and qualitative methods: the operation of the Kunsthaus Graz provides an inflow of purchasing power for the municipality of Graz; the Kunsthaus Graz has positive, long-term effects in the fields of tourism marketing, civic pride and identification, creative industries and urban regeneration; the effects of the Kunsthaus Graz are spatially concentrated in the municipality of Graz.
\end{abstract}

Keywords: Effects, star architecture, spatial incidence analysis, Bilbao Effect, urban regeneration, Graz

Kurzfassung: Nach der Eröffnung des vom Stararchitekten Frank Gehry entworfenen Guggenheim-Museums Bilbao haben zahlreiche Städte versucht, den ,Bilbao-Effekt' zu wiederholen in der Hoffnung, mit Stararchitekturprojekten eine positive Wirkung auf den Tourismus und die sozioökonomische Entwicklung auszulösen. Viele Projekte erreichten die mit innen verbundenen Ziele aber nicht. Ihre Rolle als Katalysator für die Stadtentwicklung wird daher in Frage gestellt. Wir argumentieren, dass die zeitliche und räumlich-ökonomische Dimension der Effekte von Stararchitekturprojekten - die in der Literatur bisher kaum diskutiert wurden - entscheidend ist, um den Beitrag solcher Projekte für die Stadtentwicklung zu beurteilen. Wir zeigen am Beispiel des Kunsthauses Graz in Österreich,

\footnotetext{
*Corresponding author: Johannes Dreher, HafenCity Universität Hamburg, Überseeallee 16, 20257 Hamburg, Germany, E-Mail: johannes.dreher@hcu-hamburg.de, ORCID: 0000-0002-5545-6350

Dr. Nadia Alaily-Mattar, Technische Universität München, Arcisstraße 21, 80333 München, Germany, ORCID: 0000-0001-5713-6548

Prof. Dr. Alain Thierstein, Technische Universität München, Arcisstraße 21, 80333 München, Germany, ORCID: 0000-0003-1878-4862
} 
wie man die Methode der räumlichen Inzidenzanalyse zur Bewertung der sozioökonomischen und intertemporalen Effekte eines Stararchitekturprojekts, das mit öffentlichen Geldern gefördert wurde, anpassen und nutzen kann. Die räumliche Inzidenzanalyse ist einer Kosten-Nutzen-Analyse ähnlich, berücksichtigt jedoch die räumlichen und zeitlichen Verteilungseffekte dreier zusammenhängender Dimensionen: Zahlungsströme, Güter und Dienstleistungen, Nutzen. Durch eine Kombination von quantitativen und qualitativen Analysen gewinnen wir folgende Erkenntnisse: Der Betrieb des Kunsthauses Graz sorgt für einen Kaufkraftzufluss der Gemeinde Graz, es zeigt positive, langfristige Effekte in den Bereichen Tourismusmarketing, Bürgerstolz und -identifikation, Kreativwirtschaft und Stadterneuerung. Zudem konzentrieren sich die Wirkungen des Kunsthauses Graz räumlich auf die Gemeinde Graz.

Schlüsselwörter: Effekte, Stararchitektur, räumliche Inzidenzanalyse, Bilbao-Effekt, Stadterneuerung, Graz

\section{Star architecture projects and the 'Bilbao Effect'}

Discussions about star architecture projects are dominated by the 'Bilbao Effect' narrative. Star architecture projects are projects that are designed by architects who are publicly recognized for their professional standing. The Guggenheim Museum Bilbao by star architect Frank Gehry had an apparently positive effect on Bilbao's transformation process from a declining industrial city into a popular destination for tourists and the service industry; this came to be known as the Bilbao Effect (Haarich/Plaza 2010: 5). Discussions about the Bilbao Effect often ignore the fact that the construction of the Guggenheim Museum Bilbao was embedded in an extensive urban development plan (Haarich/Plaza 2010: 5; Plaza/Haarich 2015: 1460). Consequently, the term is often misleadingly equated with a causal relationship between the Guggenheim Museum Bilbao and the rise of the city (Plaza/Haarich 2015: 1460). The success of the Guggenheim Museum and the seemingly simple formula have aroused a desire for emulation worldwide (Jencks 2006: 8; Klingmann 2007: 247, 248). The Bilbao Effect has become an urban policy "in motion" (González 2011), an urban development strategy that has been imitated internationally. Cities expect physical and economic regeneration and hope to reposition themselves in international urban competition with the help of such projects (Jencks 2004; Alaily-Mattar/Dreher/ Thierstein 2018; Alaily-Mattar/Bartmanski/Dreher et al. 2018). However, various researchers are aware that positive effects such as those observed in Bilbao cannot be guaranteed (e.g. Klingmann 2007: 250; Heidenreich/ Plaza 2015: 1442). The effect of star architecture projects as catalysts for positive socio-economic urban development is therefore debatable (Evans 2005: 977).

As yet, there have been hardly any investigations into the long-term effects and the spatial distribution of the effects of star architecture projects (Evans 2005: 974-975; Dreyer 2016). We argue that the investigation of long-term effects and the spatial distribution of these effects is crucial for assessing the effectiveness of star architecture projects as tools for urban regeneration.

The paper presents the spatial incidence analysis and discusses, drawing on the case study of the Kunsthaus Graz, the application and ability of this methodological framework to analyse and assess the spatial distribution of socio-economic effects of public star architecture projects. By incorporating a combination of quantitative and qualitative methods, the spatial incidence analysis has proven to be a flexible framework that furthers our understanding of the spatial and intertemporal effects of star architecture projects. The paper identifies and assesses a range of long-term effects of the Kunsthaus Graz for the spatial institutional levels of the municipality, the federal state, the national state and foreign countries.

In the following section, we first introduce the term 'star architecture', followed by a literature review of the socio-economic effects of star architecture. The methodology of the spatial incidence analysis is explained in the third section. The fourth section presents the results of our case study, the Kunsthaus Graz in Austria. The fifth section serves to discuss the empirical results. We then wrap-up with conclusions and highlight the need for further research.

\section{A literature review of the socio-economic effects of star architecture}

The terms iconic architecture (Sklair 2006; Jencks 2011), flagship architecture (Weidenfeld 2010) and star architecture (Foster 2008; Ponzini 2011; Gravari-Barbas/ 
Renard-Delautre 2015; Ponzini/Nastasi 2016) are used in the scientific discourse on the Bilbao Effect. While the terms iconic architecture or flagship architecture anticipate the possible effect of the buildings (Weidenfeld 2010), the term star architecture emphasizes the significance of the fame of the architect, but leaves open the question as to whether an effect in the sense of an icon, a flagship or any effect at all sets in. Alaily-Mattar, Bartmanski, Dreher et al. (2018: 1876-1879) argue that star architecture is not simply an output, but also a bundle of various, tightly intertwined aspects, forming a process that they call star architecture projects. According to their definition, star architecture projects are regarded as a "(1) a process, (2) of designing and constructing a physical structure (3) by an internationally renowned architect, (4) to house a civic institution, (5) on a strategically identified urban site, (6) in order for star architecture to perform particular functions, (7) each of which is enacted over time according to specifies of the location (8) resulting in sets of localized meanings". We refer to this definition in the paper and include not only effects of the output, but also of the process of implementing star architecture projects in our investigation.

The scientific debate on the socio-economic effects of star architecture projects rejects the assumption that a single building can generate a Bilbao Effect. Instead, researchers emphasize the necessity of acknowledging the embedding of architectural projects in urban development strategies (e.g. Baudelle 2015: 1490; Heidenreich/Plaza 2015: 1441-1443) and their dependence on individual context factors (Plaza 2013: 65; Franklin 2016: 90; Ponzini/Nastasi 2016: 187, 193-197; Alaily-Mattar/Bartmanski/Dreher et al. 2018: 1894-1895).

The use of star architecture to successfully boost the image of cities is also widely recognized. In this context, the building can become a representative (marketing) symbol of urban regeneration or of the city and promote its branding and value (Plaza 2000: 273; Klingmann 2007: 240; Plaza 2008: 514; BMVBS 2011: 48; Smith/von Krogh Strand 2011: 93; Plaza 2013: 64; Heidenreich 2015: 1529; Heidenreich/Plaza 2015: 14481449). The marketing of a city through architecture is also referred to as "architourism" (Ockman/Frausto 2005), "architainment" (Fernández-Galiano 2005), "iconomy" (Smith 2008: 3) or "brandscape" (Klingmann 2007). A study of the mechanisms of effects of the Kunsthaus Graz confirms that the physical appearance of the building, its architecture, has a positive effect on city marketing and changes in the image of the city (Dreher/Alaily-Mattar/Thierstein 2020a: 36-37). Plaza, Gonzáles-Casimiro, Moral-Zuazo et al. (2015) have shown that brand value, promoted by an accumulation of images of the star architecture in the media, is reflected in tourist visits and thus leads to economic revenue. However, Alaily-Mattar, Büren and Thierstein (2019: 45-46) demonstrate with the help of three case studies that star architecture projects do not necessarily lead to increased media attention for a city in the long term.

Star architecture projects with a cultural function can make a valuable contribution to research, creative and innovative activities in cities. They can be an important resource for educational institutions (Bryan/Munday/ Bevins 2012: 149) and promote the dissemination of scientific knowledge (Heidenreich/Plaza 2015: 1453; Lazzeretti/Capone 2015: 1548). As a meeting place for artists, creative people, companies, educational institutions, politics and citizens, museums can act as "societal engines" thus contributing to social and cultural enhancement (Lazzeretti/Capone 2015: 1550), support the formation of networks and lead to interdisciplinary stimulation (Heidenreich 2015: 1529). Projects by star architects can promote local-global corporate ties through integration into global networks and links to important institutions and actors. In this way, projects can facilitate access to new sources of finance and act as pioneers for specialized knowledge and services (Plaza/Haarich 2015: 1471-1472).

While the majority of studies investigate specific or isolated effects of star architecture projects, recent research focuses on the range of effects of star architecture projects. A multidisciplinary investigation of three case studies shows how socio-cultural, urban morphological and socio-economic effects contribute to the repositioning of cities (Alaily-Mattar/Bartmanski/ Dreher et al. 2018). The work of Dreher, Alaily-Mattar and Thierstein (2020b) stresses the range of socio-economic effects and examines how star architecture projects 'work'. They analyse which elements of the projects generate the observed effects. For this purpose, they utilize a conceptual impact model that was developed during the research process (Alaily-Mattar/Dreher/ Thierstein 2018: 177; Alaily-Mattar/Dreher/Wenner et al. 2018: 47; Thierstein/Alaily-Mattar/Dreher 2020: 49).

Negative consequences of star architecture projects, such as socio-spatial polarization, are demonstrated by Rodríguez Martínez and Guenaga (2001: 175-176), Vicario and Martínez Monje (2003: 2398), González (2011: 1414), Girgert (2011) and Baudelle (2015: 14871489). Rius-Ulldemolins, Hernandez Marti and Torres (2015: 71) stress that spending on public star architecture projects is a financial burden that may be too much 
to bear for communities and can thus lead to "the disappearance of almost all cultural and sports projects" (Rius-Ulldemolins/Hernandez Marti/Torres 2015: 71).

The temporality of the effects of star architecture projects is a topic of controversial discussion, especially with regard to a number of economic effects. Some authors identify clear economic and tourist effects that are seen as an important contribution and stimulus to the development of economic restructuring (Plaza 2000: 273; Plaza 2006: 464; Plaza 2008: 514; Smith/von Krogh Strand 2011: 93; Krauss 2015: 1494; Heidenreich 2015: 1529; Plaza 2013: 64; Plaza/Haarich 2015: 1459). Other authors point out that these are only short-term effects and thus do not have the desired effect, e.g. on the labour market (Gómez 1998: 117-118; Jasmand/ Maennig 2008: 998-1000; Ponzini 2011: 252). Longterm effects are the decisive criteria for success when it comes to bringing about change. However, to date there have been hardly any investigations into the long-term effects of star architecture projects and their existence is therefore often doubted (Evans 2005: 961, 967, 975; Rodríguez/Martínez/Guenaga 2001: 175; Plaza/Tironi/ Haarich 2009: 1713).

Evans (2005: 975) and Baus (2015: 3) point out that even in apparently successful projects the goals are often only partially achieved, while Patterson (2012: 3292) doubts in general that the generation of economic effects for local economies is the primary concern of public star architecture projects. The question of whether it is justified to use financial resources to achieve the goals generally remains unanswered (BMVBS 2011: 3; Rius-Ulldemolins/Hernandez Marti/Torres 2015: 71). Proof of utility is particularly relevant in the continental European context, where star architecture projects with cultural functions are typically merit goods (Musgrave 1987) that are publicly financed at the spatial-institutional levels of the nation state, federal state and municipality. The expenditure of taxpayers' money for merit goods has to be legitimized by the demonstration of utility. Because star architecture projects generate costs and utility that are usually distributed unequally in terms of space and institutions, a spatial analysis is necessary to assess the costs and benefit balance at the different spatial-institutional levels involved in financing. Evans (2005: 974-975) and Dreyer (2016) also attach central importance to the spatial distribution of the effects of star architecture projects. However, they furthermore note that there is hardly any research into this issue. With regard to spatial effects, the authors are only aware of studies by Plaza, Tironi and Haarich (2009) into the spatial reorganization of the arts market cluster in
Bilbao and the study by Ahlfeldt and Mastro (2012) into the external price effects of iconic architecture on the housing market.

The extent to which star architecture projects do in fact generate the expected socio-economic effects and thus contribute to urban regeneration remains unclear. Whether these projects generate long-term effects and where these effects are spatially distributed are crucial questions for any assessment of a star architecture project's potential for urban regeneration. However, hardly any of the existing scientific literature deals with these issues. The aim of this paper is to address these research questions. We use a spatial incidence analysis (Frey/Häusel 1982) to investigate the long-term effects of a star architecture project and the spatial distribution of these effects. This research methodology investigates whether long-term effects arise from the projects and at the same time analyses the spatial disparity of costs and utility. The following chapter describes the spatial incidence analysis.

\section{Methodology and selection of the case study}

\subsection{Analytical framework and methods applied}

We use the spatial incidence analysis to assess the spatial distribution of the socio-economic effects of star architecture projects. The methodology originates from the incidence analysis developed by Musgrave, Musgrave and Kullmer (1977) for the public finance sector that examines the effects of fiscal policy measures. They assume that a change in tax legislation will lead to a chain of economic adjustment processes through which the tax burden is shifted. The adjustment processes for households and companies serve as an example: companies that have a higher tax burden can pass this on to or share it with their customers in the form of higher prices. The incidence analysis determines the final, effective distribution of the tax burden after this adjustment process (Musgrave/Musgrave/Kullmer 1977: 4). Frey and Häusel (1982) have adapted the methodology to analyse the spatial effects of regional infrastructure projects. The spatial incidence analysis is similar to a cost-benefit analysis, with one decisive difference: the spatial incidence analysis investigates the temporal and spatial distribution of benefits and costs, advantages and disadvantages (Frey/Häusel 1982; Frey 
1984; Fischer/Wilhelm 2001; Zimmermann/Henke 2001: 237; Scherer 2002; Scherer/Strauf/Riser et al. 2012).

The spatial incidence analysis is structured according to the spatial-institutional levels that finance the infrastructure measure. In decentralized and federalist states, public infrastructure is usually financed by the municipality, the federal state and the nation state. The analysis also differentiates between three analyses of spatial incidence: payment flows, goods and services, and utility. The methodology allows a comparison of the resulting financial effects, the goods and services produced, and the utility generated at the different spatial-institutional levels.

The incidence analysis of payment flows investigates financial effects, or more precisely the inflow or outflow of purchasing power, that arises from the operation of the infrastructure project for the municipality, the federal state or the nation state. All payments related to the operation of the project are spatially allocated to the spatial-institutional levels involved in financing. The incidence analysis of goods and services examines the supply of goods and services by the infrastructure project to the municipality, the federal state or the nation state. Goods, such as the physical building, and the services provided therein, such as an art exhibition, are examined with regard to their use. The analysis requires information on the origin of the users in addition to the intensity of the demand over time.

The analyses of payment flows and of goods and services are quantitative and examine the change in purchasing power or the use of the project. The incidence analysis of utility, on the other hand, is an individual analysis that examines the various projectspecific benefits, i.e. the various positive effects of the project for the municipality, the federal or the nation state. The utility is often difficult to express in figures and is therefore described qualitatively (Frey/Häusel 1982: 20; Frey 1984: 42-44, 50).

A consideration of the long-term effects of public infrastructure projects is of particular importance for the analysis of utility. Short or medium-term effects are directly linked to the realization of the projects and do not entail any changes with sustainable effects. By contrast, long-term effects lead to stable, structural adjustment effects, e.g. changes in the labour market (Frey 1984: 43). Evaluation research also stresses that sustained changes or impacts can only be achieved through long-term effects (Julian 1997; Weiss 1997; McLaughlin/Jordan 1999). Long-term effects are also of crucial importance in the case of star architecture projects since the proponents of the projects use the expected, positive, long-term effects on the socioeconomic development of their cities as a central argument for legitimizing taxpayer money expenditure. This study therefore focuses on the analysis of longterm effects. The analysis provides information on the extent to which the city's self-imposed project goals have been achieved, whether additional, unintended positive effects have been generated, the extent to which the use of public funds yields utility (Musgrave/ Musgrave/Kullmer 1977; Frey/Häusel 1982; Frey 1990), and whether the state is fulfilling its sovereign task of using tax revenues efficiently and effectively.

We divide the study into four main analytical steps: 1) the analysis of the objectives associated with the project, 2) the incidence analysis of payment flows, 3 ) the incidence analysis of goods and services and 4) the incidence analysis of utility (see Table 1). Project-related documents prepared for or by the municipality (e.g. strategic development plans that reveal the ambitions to become European Capital of Culture (ECOC) and to develop the Kunsthaus Graz, the competition brief for Kunsthaus Graz, the feasibility analysis) were analysed and 15 semi-structured interviews were conducted with the initiators and project managers to analyse the objectives associated with the star architecture projects.

We performed the spatial incidence analysis of payment flows by evaluating the accounting of the Kunsthaus Graz. A spatial evaluation was possible thanks to the cooperation of the Kunsthaus Graz and the assignment of all incoming and outgoing payments to the different spatial-institutional levels. In order to determine the spatial incidence of goods and services, we restrict ourselves to the use of the main function of the Kunsthaus Graz, namely exhibitions. We evaluate spatial data for visitors to the exhibition. Information on the number of visitors and their origin was provided by the Kunsthaus Graz. For the analysis of the spatial incidence of utility, we conducted 15 semi-structured interviews with local experts to determine the various effects. We extended the methodology at this point and adapted it to the specifics of star architecture projects. In addition to interviews, we used different methods and triangulations to verify the effects perceived by the local experts and to assess the significance of these effects for the socio-economic development of the city. We used interviews and existing surveys and analysed socio-economic longitudinal data (overnight stays, development of firms in the creative industry) to investigate the effects on tourism and the creative economy in the city of Graz. Interviews and existing 
Table 1: Framework of Spatial Incidence Analysis

\begin{tabular}{lll}
\hline Item of analysis & Item of utility analysis & Research methods used and data \\
\hline Objectives of project & & Interviews; document analysis \\
\hline Payment flows & Evaluation of accounting data \\
\hline Goods and services & Evaluation of visitors \\
\hline Utility & Tourism & Interviews; statistical correlation analysis; surveys \\
& Civic pride and identification & Interviews; surveys \\
& Creative industries & Interviews; statistical correlation analysis \\
& Urban regeneration & Interviews; analysis of start-ups; morphological analysis \\
\hline
\end{tabular}

surveys were also used to determine effects on civic pride and identification. The effects on urban regeneration were revealed with the help of interviews, an analysis of start-up businesses and a morphological analysis investigating the physical urban restructuring triggered by the projects based on maps and visual relations. Our analysis of the spatial incidence of utility builds on a number of previous publications that investigated the effects of the Kunsthaus Graz (Alaily-Mattar/Bartmanski/ Dreher et al. 2018; Dreher/Alaily-Mattar/Thierstein 2020a; Dreher/Alaily-Mattar/Thierstein 2020b) but that do not stress the spatial distribution of effects or take into account the effects of payment flows or goods and services.

During our application of a spatial-institutional analysis, we differentiate between the following incidence levels: municipality, federal state, nation state, foreign countries. Table 2 evaluates the quantitative results of the analysis of the payment flows and goods and services qualitatively so that they can be compared with the results of the incidence analysis of utility. Qualitative statements helped us compare the strength of the effects between the spatial-institutional levels in the absence of numerical values in the analysis of utility. The evaluation distinguishes between the following levels of effects: strong, considerable, weak, none or negative.

\subsection{Selection of the case study}

The case study Kunsthaus Graz was selected on the basis of the following criteria. Firstly, it is a public project in a decentralized and federalist state whose funding is drawn from taxpayers' money and must hence be legitimized. Secondly, the project was awarded to an internationally renowned architect whose reputation was confirmed by the Avery database index of architectural journals ${ }^{1}$. Thirdly, at the time the research began, the Kunsthaus Graz had already been in operation for more than ten years. This period of time is important in order to verify long-term effects. Fourthly, the project is located in a city with less than 300,000 inhabitants. Limiting the size of the city should help to better identify socio-economic effects. In medium-sized cities the allocation of public funds is especially selective, focused and subject to a higher level of control over the effective use of taxpayers' money.

\section{Case study: Kunsthaus Graz}

The Kunsthaus Graz is an exhibition centre for contemporary international art. It was designed by Peter Cook and Colin Fournier and opened in 2003 in the Austrian city of Graz as part of the events organized for the city's designation as the European Capital of Culture in 2003. The Kunsthaus Graz is a public project financed by the municipality of Graz and the federal state of Styria. The presentation of the empirical findings begins with the genesis of the project and the associated socio-economic goals. The analysis of the incidence of payment flows, of goods and services and of the utility then follow. Finally, Table 2 summarizes the findings and presents an overview of the observed effects on the spatial-institutional levels.

1 The Avery database (https://library.columbia.edu/libraries/ avery/avery-index.html; 11.09.2020) is a collection of articles from international architectural journals. The repeated mentions of the architects in these professional articles are an indication of their international reputation. 


\subsection{Genesis and objectives of the Kunsthaus Graz}

The Kunsthaus Graz is located in the city of Graz, the capital of the state of Styria. With around 284,000 inhabitants (2017), Graz is the second largest city in Austria. The Kunsthaus Graz was developed in the Lend district on a brownfield site used as a car park on the banks of the River Mur. The plot is located close to the historical city centre but is separated from it by the River Mur. The aim was to strengthen the connection between the run-down district of Lend and the historical city centre (Schneider 2012: 60; Interview 1; Interview 2) ${ }^{2}$, because Graz was perceived as a city sharply divided by the river (Interview 1). The historical centre was characterized by bourgeois life and cultural institutions, whereas the Lend district on the other side of the river was a working-class district that had little to offer culturally (Dienes 2009; Kubinzky 2009). The upgrading of the Lend district was connected with the development of the Kunsthaus Graz.

Graz has an important cultural tradition as a royal residence and a city of education and culture, and it has a formative architectural landscape. The image of Graz, however, suffered from its association with the automobile industry, reflected by the city's nickname "Detroit-in-the-Alps" (Zakarias/Gertzmacher/Gruber et al. 2002: 48). Graz was also regarded as a "Pensionopolis" (Klute 2003: V2/1), a conservative retirement home for pensioners. These negative association "offended" the city (Interview 3 ) as the cultural heritage of Austria's second largest city was hardly recognized and smaller Austrian cities such as Salzburg or Innsbruck received more media attention and were more popular tourist destinations. The city also suffered from a "lack of international attention" (Zakarias/Gertzmacher/Gruber et al. 2002: 45) and from unclear identification and vision, "Graz did not know what to do with itself" (Interview 2). Through its designation as European Capital of Culture, Graz wanted to strengthen its international reputation as a city of art and culture on a European level. For this purpose, the Kunsthaus Graz was the "main responsible project" in the ECOC programme ${ }^{3}$ (for more information see also Dreher/Alaily-Mattar/Thierstein 2020b: 156). The city officials expected the Kunsthaus Graz to become a symbol of Graz, European Capital of Culture 2003, to

2 For decoding of interviews see table at the end of this paper. 3 The Application, Philosophy and Project History and The Communication Management; see http://www.kultur.graz.at/ kulturamt/158 (11.09.2020). attract international attention to the city ${ }^{4}$ (Interview 4$)^{5}$ and to give Graz a unique selling point and thus promote tourism (Zakarias/Gertzmacher/Gruber et al. 2002: 45).

\subsection{Spatial incidence analysis of payment flows}

The spatial incidence analysis of payment flows investigates the financial effects that the operation of public projects will have on the municipality, federal or nation state. An analysis of the spatial allocation of the Kunsthaus Graz' payment flows between 2005 and 2013 shows that the municipality of Graz benefits from an inflow of purchasing power of $€ 5.8$ million (see Figure 1). The division of the financing costs of the Kunsthaus Graz between the municipality and the federal state of Styria largely explains the long-term positive result of the purchasing power inflow for the municipality of Graz. Graz pays one third of the building lease costs and $45 \%$ of the operating costs, the federal state of Styria pays two thirds of the lease costs and $55 \%$ of the operating costs (Landesrechnungshof Steiermark 2008). In the period under review, expenditure by the Kunsthaus Graz also benefitted Austria with $€ 5.4$ million and foreign countries with $€ 2.0$ million. The federal state of Styria has a negative balance of $-€ 13.2$ million due to the high level of subsidies.

\subsection{Spatial incidence analysis of goods and services}

The spatial incidence analysis of goods and services examines the use by the municipality, the federal state or the nation state of the goods and services provided by the project. The analysis of the number of visitors to the exhibitions shows that the expectation of 100,000 visitors per year (Fritz/Pointner/Steiner et al. 2001: 1) has not been met. The number of visitors decreased by $22 \%$ from 81,017 in 2005 to 63,232 in 2013. ${ }^{6}$ Most of the visitors to the exhibitions come from abroad (approximately $40 \%$ ). Visitors from the federal state and the municipality cannot be differentiated based on the available data. Both together account for around $40 \%$. About $20 \%$ of all

\footnotetext{
4 See http://www.Museum-joanneum.at/kunsthaus-graz/ueber-uns (05.09.2020).

5 See also The Communication Management; http://www.kultur. graz.at/kulturamt/158 (11.09.2020).

6 Data source: Universalmuseum Joanneum, unpublished data.
} 


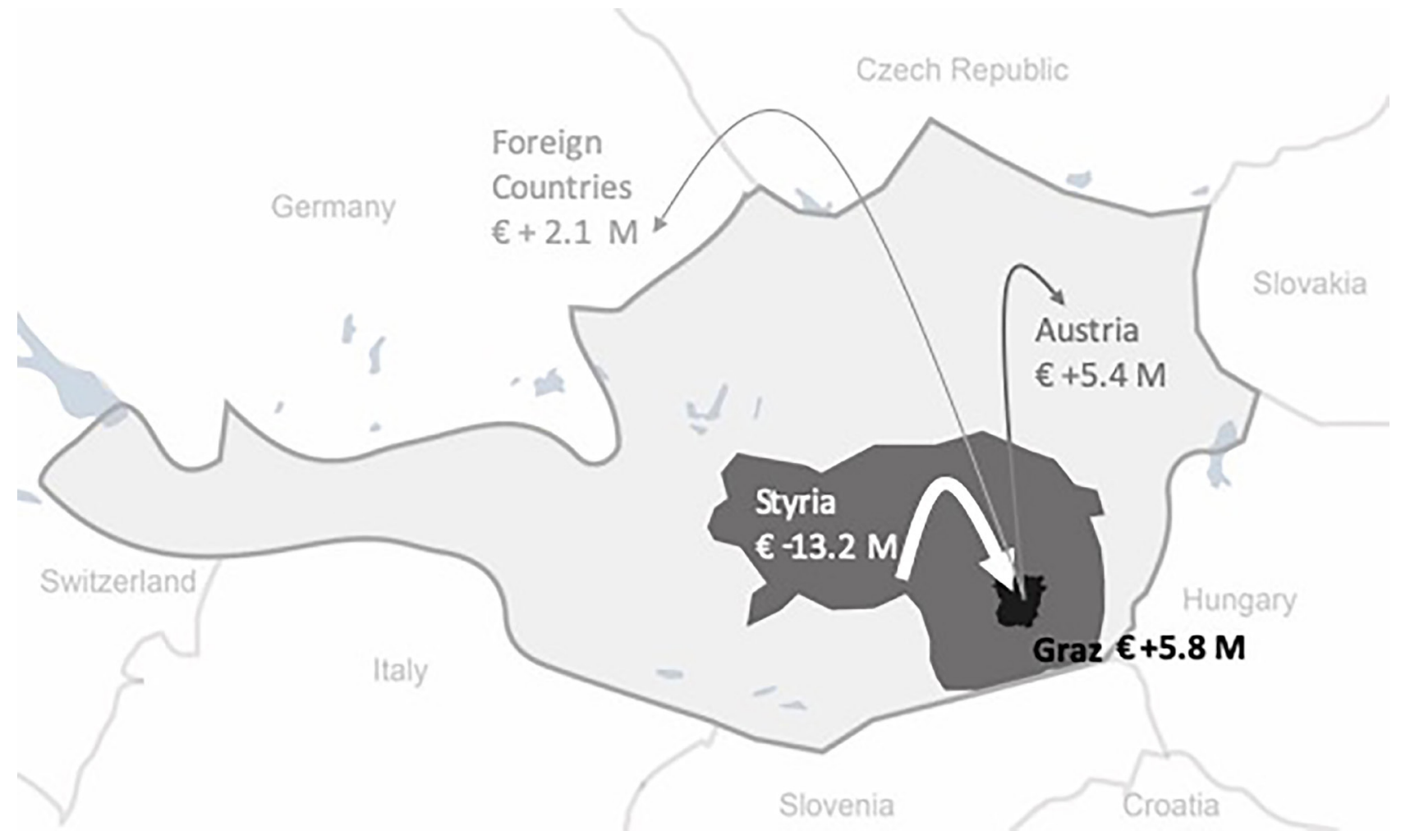

Figure 1: Visualization of the spatial distribution of payment flows for the Kunsthaus Graz 2005-2013

Calculation by the authors, data source: Universalmuseum Joanneum, unpublished data

visitors come from the nation state. The proportions of the various groups of different origin were stable over the period under consideration and hardly changed.

\subsection{Spatial incidence analysis of utility}

The spatial incidence analysis of utility investigates the extent to which the Kunsthaus Graz generates positive effects for the socio-economic development of the municipality, the federal state or the nation state. By analysing documents and holding interviews, we identified the following expected or observed effects of the Kunsthaus Graz: support for tourism, strengthening of civic pride, support for the creative industry and urban regeneration of the Lend district. We reviewed and evaluated these effects by applying qualitative and quantitative research methods.

\subsubsection{Support for tourism}

The correlation analysis of the number of visitors to the Kunsthaus Graz and the number of overnight stays in
Graz shows no positive results. Whereas the number of visitors to the Kunsthaus Graz declined (101,300 in 2003; 65,000 in 2013), ${ }^{7}$ the number of overnight stays in Graz rose (from approximately 832,400 overnight stays in 2003 to approximately $1,080,400$ in 2015). ${ }^{8}$ Therefore, we cannot prove statistically that the Kunsthaus Graz has contributed to an increase in overnight tourism. However, we cannot rule out the possibility that the Kunsthaus Graz attracts tourists. Grohmann (2007: 23) confirms a "sustainable tourist use" of the Kunsthaus Graz in a survey of 300 visitors to the building. One third of the respondents stated that they visited the Kunsthaus Graz as part of a tourist trip (without information on overnight stays). Surveys of passers-by show that the Kunsthaus Graz is a trademark of Graz (HLW Schrödinger 2014) and by far the best-known building (Passegger 2006: 9). A clear majority of people passing by the Kunsthaus Graz (35\% of the citations) particularly like the architecture (survey by Passegger 2006: 22). Pictures of the Kunsthaus Graz are frequently and regularly

7 Data source: Universalmuseum Joanneum, unpublished data. 8 Data source: Statistik Austria; https://statcube.at/statistik.at/ext/ statcube/jsf/tableView/tableView.xhtml (11.09.2020). 
used in marketing brochures of Graz Tourismus $\mathrm{GmbH}$. This underlines the importance of the architecture of the Kunsthaus Graz for tourism (Dreher/Alaily-Mattar/ Thierstein 2020a: 36-37). The analysis of the interviews with local experts confirms that the architecture is seen to support tourism eminently more than the exhibition function (Interviews 1, 4, 5, 6, 7).

\subsubsection{Civic pride and identification}

Our interviewees state that the citizens like the Kunsthaus Graz and that they are very proud of it. This perception is confirmed in a survey by HLW Schrödinger (2014) which shows that the majority of the citizens who were interviewed have a positive attitude towards the Kunsthaus Graz. The analysis of our interviews reveals that citizens identify with the building, they see it as their common representative, their new landmark. Interviewee 7 states, "it belongs to the identity of the city". An analysis of the images of the city of Graz on the Flickr photosharing platform ${ }^{9}$ confirms these findings (Alaily-Mattar/ Büren/Thierstein 2019: 42). The share of all pictures of Graz uploaded on Flickr that are tagged with Kunsthaus Graz is $2.2 \%$, whereas the share of pictures tagged with Graz' previous landmark, the clock tower, only amounts to $0.7 \%$. Additional evidence that the Kunsthaus Graz is an object of identification and new landmark for Graz is the frequent use of images of the Kunsthaus Graz in tourist marketing brochures and the survey by HWL Schrödinger (2014) attesting that the Kunsthaus Graz is one of the most popular buildings in the city.

The Kunsthaus Graz also fostered pride and strengthened the courage of citizens and city officials due to the successful realization of the star architecture project, as explained in Interview 5, "it was a demonstration and an important finding, that Graz is able to play along at the European level". As a permanent material symbol and highlight of the temporary ECOC event, the Kunsthaus Graz is a lasting reminder of a successful international event when Graz was a cultural hotspot in Europe. The Kunsthaus Graz with its exceptional design, "became a symbol for a courageous city" (Interview 2), it boosted the self-confidence of citizens and acted as a forwardlooking icon (Interview 3), "whereby a new spin is put on the city's own logic" (Alaily-Mattar/Bartmanski/Dreher et al. 2018: 1886-1887).

9 https://www.flickr.com (11.09.2020).

\subsubsection{Support for the creative industry}

One form of this future-oriented identification can be seen in the use of the Kunsthaus Graz to promote the creative industries in Graz. In 2009, six years after its opening, the Kunsthaus Graz played a central role in the city's bid for the title UNESCO City of Design. ${ }^{10}$ The image of the Kunsthaus Graz was placed prominently on the cover of the application as a symbol of a modern and design-oriented city. Through the successful application and the associated integration into the networks of UNESCO Cities of Design and UNESCO Creative Cities, the Kunsthaus Graz has contributed to establish global connections. Our analysis of the creative industry in Graz shows that the number of workplaces - companies and branches - grew by $83 \%$ between 2001 and 2014, more strongly than the average of all workplaces in Graz $(+59 \%)$.

Within the creative industries, the subsector art/ culture/design has strong links to the Kunsthaus: its business activities correlate with the function of the Kunsthaus, the Kunsthaus is an important event location for this subsector, the Kunsthaus internationally represents this subsector as an icon (Interview 4), and this subsector tends to spatially concentrate around the Kunsthaus (see Sedlmeier 2016). The art/culture/design subsector grew more strongly between 2001 and 2014 (+ $66 \%$, highest absolute growth of 677 workplaces) than subsectors without such strong connections to the Kunsthaus Graz (-22\%). ${ }^{11}$ Even if a precise measurement of the effect of the Kunsthaus Graz on the expansion of creative industries is not possible as other factors are also relevant, this analysis supports the observations of the interviewed experts who attach great importance to the role played by the Kunsthaus Graz in supporting the development of the creative industries. The Kunsthaus was essential in the initial phase to pave the way towards becoming a creative design city. The founding of the networking association Creative Industries Styria (CIS), the Design Month Graz and other initiatives are additional examples of this development. However, this development must be seen against the background of the entire labour market in Graz: the subsector of art, culture, design employs 5,015 people, only $2.54 \%$ of all employees in Graz (2014), and thus does not lead to any noticeable changes in labour market structure.

10 https://issuu.com/ciscommunity/docs/graz_cityofdesign_ application_pictu (05.09.2020).

11 Analysis by authors; data source: Statistik Austria, unpublished data. 
Table 2: Spatial Incidence Analysis of the Kunsthaus Graz

\begin{tabular}{|c|c|c|c|c|c|}
\hline Incidence of & Effects on & Municipality & Federal state & Nation state & Abroad \\
\hline Payment flows & Purchasing power & +++ & - & ++ & + \\
\hline Goods and services & Origin of visitors & ++ & ++ & ++ & +++ \\
\hline \multirow[t]{5}{*}{ Utility } & Overnight stays & 0 & 0 & 0 & 0 \\
\hline & Marketing symbol | landmark & +++ & 0 & 0 & 0 \\
\hline & Civic pride and identification & +++ & 0 & 0 & 0 \\
\hline & Creative industries & ++ & 0 & 0 & + \\
\hline & Urban regeneration & +++ & 0 & 0 & 0 \\
\hline
\end{tabular}

+++ strong effects, ++ considerable effects, + weak effects, 0 no effects, - negative effects

\subsubsection{Urban regeneration of the Lend district}

A morphological analysis of the Kunsthaus Graz and its urban surroundings demonstrates that the building and its strategic location redefine the urban space along the river and create a gateway to the Lend district. Through its amoeba-like form and its blue, high-tech façade, the building confidently confronts the historical city centre and, through morphological emancipation, creates a new relationship between the two districts (AlailyMattar/Bartmanski/Dreher et al. 2018: 1885-1886). The new relationship between the two halves of the city is reinforced by the catalytic effects of the Kunsthaus Graz on the regeneration of the Lend district. The construction of the Kunsthaus Graz created a cultural, creative milieu that led, for example, to the establishment of designers and trendy hairdressers, co-working spaces, restaurants and cafés, and to the organization of the Lendwirbel Festival, which is regarded as the city's most urban festival (Barnert/Bernard/Obernosterer et al. 2006: 28, 40; Arandelovic 2015: 88-89; Interviews 4, 8). Sedlmeier's (2016) analysis of businesses confirms that there are more creative companies in the Lend district $(27 \%)$ than in the corresponding control area of the historical centre $(7 \%)$. This observation is also supported by the greater dynamic development of startups in the Lend district. The proportion of start-ups after the Kunsthaus Graz opened was 15 percentage points higher than in the historical centre (Sedlmeier 2016). The increased appeal of the Lend district is also reflected by an increase in its population. The number of residents in the Lend district grew by $15 \%$ between 2006 and 2015 , outpacing the average for Graz $(10 \%) .{ }^{12}$ However, Leitner (2012: 167-168) points out that other measures

12 http://data.graz.at/daten/package/4d519b42-72fe-4059-837a560c6083542e (05.09.2020). have also contributed to the regeneration of the Lend district since the 1990s, such as the redesign of public squares and the construction of a pedestrian zone. Thus, the urban regeneration cannot solely be attributed to the Kunsthaus. Nevertheless, the outstanding role of the Kunsthaus Graz is clear as the Kunsthaus Graz is the only contemporary building in its environment and "it visually transformed the whole area" (Arandelovic 2015: 87).

Table 2 shows the spatial distribution of the analysed effects and their relative strength per spatial-institutional level. The incidence analysis of payment flows (first line) shows, for example, that payment flows for the Kunsthaus Graz have strong effects for the municipality, considerable effects for the nation state, weak effects for abroad and negative effects for the federal state.

\section{Discussion: Socio-economic effects of the Kunsthaus Graz and their spatial distribution}

The application of a spatial incidence analysis has shown that the Kunsthaus Graz creates long-term socio-economic effects. We can see positive effects of the Kunsthaus Graz at the level of payment flows and the incidence analysis of utility shows that the Kunsthaus Graz has supported city marketing, civic pride and identification, the creative industries and urban regeneration in the Lend district. Thus, we provide contrasting insights to those of Evans $(2005: 967,975)$ or Rodríguez/Martínez/Guenaga (2001: 175) who express doubts about the long-term effects of star architecture projects. This divergent finding may be explained by the use of the spatial incidence analysis and our research 
design, which both explicitly focus on long-term effects. However, this is the finding of one specific case study, applying the method to other case studies might reveal different results.

The longitudinal analysis allows us to identify the interactions of various effects that only emerge over time. The effects of the Kunsthaus Graz in terms of supporting the creative industries is a good example of this. The positive experience of the project development boosted the self-confidence of local stakeholders, encouraging them to implement new international projects, while the architecture of the Kunsthaus Graz strengthened the identification of Graz as a modern city of art and culture. This experience and use of the image of the Kunsthaus Graz as a marketing symbol for a modern, design-oriented city helped in the successful application for the title of UNESCO City of Design in 2009, six years after the opening of the Kunsthaus. The interaction of socio-cultural effects with physical-morphological and economic effects over time will only become visible in years to come.

Although we can demonstrate the long-term effects of the Kunsthaus Graz, we nevertheless have to admit that it has not achieved all of its goals. The number of visitors is lower than expected and we could not prove any effects on overnight tourism. This aspect matches the observations made by Patterson (2012: 3292), Evans (2005: 977) and Baus (2015: 3), namely that star architecture projects often do not, or only partially, fulfil the socio-economic goals. Unlike Plaza's studies in Bilbao (Plaza 2006: 464; Plaza 2008: 514), our correlation analysis of the number of visitors to the Kunsthaus Graz and the number of overnight stays in Graz does not indicate a boost to tourism from the star architecture project. The following reasons may be an explanation for this rather sobering finding: analysis of the interviews with local experts shows that it is above all the architecture that is important for tourism, rather than the exhibition function (Interviews 1, 4, 5, $6,7)$. Therefore, the Kunsthaus Graz is not so much a flagship which, according to Weidenfeld (2010: 851-853), motivates people to step inside. Rather, the Kunsthaus functions as an icon, a symbol for the city that attracts tourists but does not necessarily motivate them to enter (Weidenfeld 2010: 851-853). The extent to which the 'icon' Kunsthaus Graz promotes overnight tourism in Graz therefore cannot be quantified on the basis of the number of visitors to the exhibition. A second explanation for the lack of a positive correlation between the number of visitors and the number of overnight stays is provided by our analysis of the incidence of goods and services.
This shows that a large share of visitors (around 40\%) comes from the municipality or the federal state. The spatial proximity of the visitors' origin to the Kunsthaus Graz suggests that their visits are in the course of day trips. Day-trip tourism seems to play an important role, but is unfortunately not recorded statistically, therefore it is not possible to verify any statistical correlation.

Our paper provides important answers to the questions raised by Evans (2005: 974-975) and Dreyer (2016) about the spatial effects of star architecture projects. The spatial incidence analysis shows that the effects of the Kunsthaus Graz are evident not only at the spatial-institutional level of the municipality, but also for the federal state, at the national level and even beyond (see Table 2). The study, however, illustrates the concentration of effects at the spatial-institutional level of the municipality. The incidence analysis of payment flows and utility show the strongest effects for the municipality. The results of the incidence analysis of goods and services are inaccurate for the municipality due to the available data; data for the municipality cannot be separated from that for the federal state. However, both spatial-institutional levels together show strong effects. The synopsis of the different incidence analyses clearly demonstrates that the spatial-institutional level of the municipality of Graz profits most from the project financially (with a plus of $€ 5.8$ million, 2005-2013) and the incidence of utility shows that all identifiable effects are strongest in the municipality, or only occur there, with one exception. Unlike the study by RiusUlldemolins, Hernandez Marti and Torres (2015: 71), the case of the Kunsthaus Graz does not show that the project represents an exceptionally high financial risk for the municipality. However, the positive result of the incidence of payment flows for the municipality is only possible thanks to the participation of the federal state in the financing of the Kunsthaus Graz, as the state thus assumes part of the financial risk.

We identify, describe and assess the effects of the Kunsthaus Graz at the level of the incidence of utility. However, we cannot measure these effects exactly or analyse the extent to which these effects have socioeconomic impacts. According to Thierstein, Alaily-Mattar and Dreher (2020: 47-48) there is a linear relationship between effect and cause, and effects can therefore be traced back to the star architecture projects, while impacts on the socio-economic development are multidimensional and multiscalar processes that are influenced by known and unknown effects. In this context especially the potential effects of the wider ECOC Programme have to be taken into account. We can link 
observed effects to impacts, but we cannot measure the extent to which the different effects cause impacts (Thierstein/Alaily-Mattar/Dreher (2020: 47-48).

We did not observe a strong transformation of socio-economic conditions in Graz that is related to the observed effects of the Kunsthaus Graz. Hence, the Kunsthaus Graz did not act as a socio-economic 'game changer' for the city. Consequently, we cannot dispel the doubts voiced by Evans (2005: 977) and Patterson (2012: 3289) as to whether star architecture projects are suitable catalysts for positive urban development, or the doubts of Rius-Ulldemolins, Hernandez Marti and Torres (2015: 71) as to whether the financial resources deployed are justified by the goals that are achieved.

\section{Conclusion and outlook: Applying spatial incidence analysis to analyse the socio- economic effects of star architecture projects}

Our application of the spatial incidence analysis to a star architecture project to assess its socio-economic impacts provides sophisticated insights into the longterm effects of star architecture projects and their spatial distribution. More than ten years after the inauguration of the Kunsthaus Graz, we notice an influx of purchasing power for the spatial-institutional level of the municipality of Graz due to the operation of the Kunsthaus Graz, and show that the Kunsthaus Graz supports city marketing, civic pride and identification, the creative industries and urban regeneration in the Lend district. The analysis of the spatial distribution of the effects shows that they are concentrated at the spatial-institutional level of the municipality. The comparison of the different incidence levels shows that the municipality of Graz benefits most of all the spatial-institutional levels, both financially and through the different socio-economic effects.

Moreover, the analysis of the incidence of utility shows that, in addition to economic effects, the project also produces linked socio-cultural and morphological effects. The spatial incidence analysis has hereby proven to be a flexible framework for the analysis of the various effects of the star architecture project using a variety of methods. The idea of utility helps to break away from mono-disciplinary research perspectives and methods.

Availability of and access to data are major limitations when using the spatial incidence analysis. The analysis places high demands on raw data and requires access to highly sensitive and usually proprietary data. The origin of visitors and all payments and addresses must be recorded by the institution over several years. In addition, access to the internal accounting of the institution must be guaranteed. The latter is a major hurdle and requires cooperation and a high level of trust on the part of the institution, because even in the case of public projects, insights into this highly sensitive area are by no means straightforward. The incidence analysis of payment flows and goods and services places high demands on the database, but provides clear, quantifiable results. The limitations of the methodology are visible at the level of the incidence of utility. Even though we can identify and assess effects, just how much they contribute to the socio-economic development of the city remains unclear. The question of how to isolate the impacts of star architecture projects on the socioeconomic development of cities remains an important task for further research. In addition, an investigation of any "architourism" (Ockman/Frausto 2005) or touristic effects that rely on the "iconicity" (Weidenfeld 2010) of the projects should be stressed in subsequent studies. It makes methodological sense to ask tourists about their motives for visiting the respective city independently of any visit to the institution.

Policymakers should justify the initiation and legitimization of star architecture projects less by the expectation that these projects will change socioeconomic conditions for their city. Many studies have either shown that objectives have not been achieved, or have not identified any major changes. Moreover, the exact contribution of star architecture projects to the socio-economic development of cities remains unclear since their impact cannot be isolated from other imminent effects. Instead in decentralized, federalist states we suggest using the spatial incidence analysis to reveal changes in purchasing power, in the provision of cultural education offerings and utility triggered by public projects. With the help of this analysis such effects can be assessed, documented and traced back to the projects. The spatial perspective enables assessment of the cost-benefit ratio for the spatial institutional levels providing finance. Our study shows that the municipality can enjoy a net benefit through a star architecture project as the positive effects of payment flows and utility are concentrated at the spatial-institutional level of the municipality, while the municipality only has to bear part of the costs. However, our study only shows the spatial distribution of costs and benefits for an individual star architecture project. In order to verify the results 
presented in this paper on a broader level or to deduce any common principles, more evidence from research using the methodology of the spatial incidence analysis on different star architecture projects is needed.

\section{List of cited interviews:}

- Interview 1: Helmut Strobl, former Councillor of Graz, 2 February 2016

- Interview 2: Lisa Rückert, former Councillor of Graz, 1 March 2016

- Interview 3: Wolfgang Lorenz, Director of ECOC 2003 Programme, 3 March 2016

- Interview 4: Eberhard Schrempf, Managing Director of ECOC and Head of Creative Industries Styria, 2 February 2016

- Interview 5: Gerhard Ablasser, former Director of City Planning Graz, 1 March 2016

- Interview 6: Andreas Schnitzler, Public Relations Manager of the Kunsthaus Graz, 2 February 2016

- Interview 7: Wolfgang Skerget, Head of City of Design coordination office in Graz, 1 March 2016

- Interview 8: Heinz Rosmann, former Head of Urban Planning of the City of Graz, 6 February 2016

Funding information: This work is supported by the German Research Foundation (Deutsche Forschungsgemeinschaft, DFG) under Grant No. TH 1334/11-1, titled, "Star architecture and its role in re-positioning small and medium sized cities".

\section{References}

Ahlfeldt, G.M.; Mastro, A. (2012): Valuing Iconic Design: Frank Lloyd Wright Architecture in Oak Park, Illinois. In: Housing Studies 27, 8, 1079-1099. doi: 10.1080/02673037.2012.728575

Alaily-Mattar, N.; Bartmanski, D.; Dreher, J.; Koch, M.; Löw, M.; Pape, T.; Thierstein, A. (2018): Situating architectural performance: 'Star architecture' and its roles in repositioning the cities of Graz, Lucerne and Wolfsburg. In: European Planning Studies 26, 9, 1874-1900. doi: 10.1080/09654313.2018.1465896

Alaily-Mattar, N.; Büren, N.; Thierstein, A. (2019): Transforming the Media Exposure of a City through Star Architecture Projects? In: disP - The Planning Review 55, 2, 36-48. doi: 10.1080/02513625.2019.1630187

Alaily-Mattar, N.; Dreher, J.; Thierstein, A. (2018): Repositioning cities through star architecture: how does it work? In: Journal of Urban Design 23, 2, 169-192. 10.1080/13574809.2017.1408401

Alaily-Mattar, N.; Dreher, J.; Wenner, F.; Thierstein, A. (2018): Public real estate development projects and urban transformation: the case of flagship projects. In: Squires, G.; Heurkens E.; Peiser, R. (eds): Routledge Companion to Real Estate Development. Abingdon, 43-55.
Arandelovic, B. (2015): Graz, UNESCO City of Design and Historical Heritage. In: Cities 43, 78-91. doi: 10.1016/j.cities.2014.11.014

Barnert, M.; Bernard, R.; Obernosterer, U.; Rapp, C.; Rosegger, R. (2006): Integriertes Kulturstättenkonzept für Graz. Graz.

Baudelle, G. (2015): The New Louvre in Lens: A Regionally Embedded National Project. In: European Planning Studies 23, 8, 1476-1493. doi: 10.1080/09654313.2013.819075

Baus, U. (2015). Stars und „Starchitecture “(2). http://www.frei04publizistik.de/data/webserver/download/1549_Starchitecture. pdf (04.09.2020).

BMVBS - Bundesministerium für Verkehr, Bau und Stadtentwicklung (ed.) (2011): Stadtentwicklung und Image. Städtebauliche Großprojekte in Metropolräumen. Berlin. = Forschungen 150.

Bryan, J.; Munday, M.; Bevins, R. (2012): Developing a Framework for Assessing the Socioeconomic Impacts of Museums: The Regional Value of the 'Flexible Museum'. In: Urban Studies 49, 1, 133-151. doi: $10.1177 / 0042098010396242$

Dienes, G. (2009): Vor der Stadt. Eine Geschichte der Grazer Bezirke Lend und Gries. Von den Anfängen bis zur Mitte des 19. Jahrhunderts. In: Murlasits, E.; Prasenc, G.; Reisinger, N. (eds.): Gries. Lend. Geschichten, Räume, Identitäten. Graz, 11-18.

Dreher, J.; Alaily-Mattar, N.; Thierstein, A. (2020a): The Power of Star Architecture and Iconic Design: Kunsthaus Graz, Austria. In: Lindsay, G. (ed.): Contemporary Museum Architecture and Design. Theory and Practice of Place. New York, 23-42.

Dreher, J.; Alaily-Mattar, N.; Thierstein, A. (2020b): The multifarious effects of star architecture: The case of the Kunsthaus Graz. In: Alaily-Mattar, N.; Ponzini, D.; Thierstein, A. (eds.): About Star Architecture. Cham, 153-168.

Dreyer, J. (2016): China's Attempt at the 'Bilbao Effect'. In: Bloomberg City Lab. https://www.citylab.com/design/2016/05/chinas-rustbelt-tries-for-the-bilbao-effect/484508/ (04.09.2020).

Evans, G. (2005): Measure for Measure: Evaluating the Evidence of Culture's Contribution to Regeneration. In: Urban Studies 42, 5-6, 959-983. doi: 10.1080/00420980500107102

Fernández-Galiano, L. (2005): Spectacle and its Discontents or the Elusive Joys of Architainment. In: Saunders, W.S. (ed.): Commodification and Spectacle in Architecture: A Harvard Design Magazine Reader. Minneapolis, 1-7.

Fischer, G.; Wilhelm, B. (2001): Die Universität St. Gallen als Wirtschafts- und Standortfaktor. Ergebnisse einer regionalen Inzidenzanalyse. Bern.

Foster, H. (2008): Image Building. In: Vidler, A. (ed.): Architecture between spectacle and use. Williamstown, 164-179.

Franklin, A. (2016): Journeys to the Guggenheim Museum Bilbao: Towards a revised Bilbao Effect. In: Annals of Tourism Research 59, 79-92. doi: 10.1016/j.annals.2016.04.001

Frey, R.L. (1984): Die Inzidenzanalyse: Ansatz und Probleme der Erfassung von Spillovers. In: Frey, R.L.; Brugger, E.A. (eds.): Infrastruktur, Spillovers und Regionalpolitik. Methode und praktische Anwendung der Inzidenzanalyse in der Schweiz. Diessenhofen, 37-55.

Frey, R.L. (1990): Städtewachstum, Städtewandel. Eine ökonomische Analyse der schweizerischen Agglomerationen. Basel.

Frey, R.L.; Häusel, U. (1982): Infrastruktur, Spillovers und regionale Disparitäten. Zwischenbericht: Fragestellung und methodische Grundlagen. Bern. 
Fritz, O.; Pointner, W.; Steiner, M.; Streicher, G.; Zakarias, G. (2001): Analyse regionalwirtschaftlicher Effekte der Errichtung und Betreibung des Grazer Kunsthauses. Graz.

Girgert, W. (2011): Der Bilbao-Defekt. https://www.germanarchitects.com/ca/pages/page_item/23_11_bilbao (04.09.2020).

Gómez, M.V. (1998): Reflective Images: The Case of Urban Regeneration in Glasgow and Bilbao. In: International Journal of Urban and Regional Research 22, 1, 106-121. doi: 10.1111/1468-2427.00126

González, S. (2011): Bilbao and Barcelona 'in Motion'. How Urban Regeneration 'Models' Travel and Mutate in the Global Flows of Policy Tourism. In: Urban Studies 48, 7, 1397-1418. doi: 10.1177/0042098010374510

Gravari-Barbas, M.; Renard-Delautre, C. (eds.) (2015): Starchitecture(s): Celebrity Architects and Urban Space. Paris.

Grohmann, M. (2007): Besucherbefragung Kunsthaus Graz. Krems (unpublished).

Haarich, S.N.; Plaza, B. (2010): Das Guggenheim-Museum von Bilbao als Symbol für erfolgreichen Wandel - Legende und Wirklichkeit. In: Altrock, U.; Huning, S.; Kuder, T.; Nuissl, H.; Peters, D. (eds.): Symbolische Orte. Planerische (De-) Konstruktionen. Berlin, 150-166. = Planungsrundschau 19.

Heidenreich, M. (2015): The New Museum Folkwang in Essen. A Contribution to the Cultural and Economic Regeneration of the Ruhr Area? In: European Planning Studies 23, 8, 1529-1547. doi: 10.1080/09654313.2013.817545

Heidenreich, M.; Plaza, B. (2015): Renewal through Culture? The Role of Museums in the Renewal of Industrial Regions in Europe. In: European Planning Studies 23, 8, 1441-1455. doi: 10.1080/09654313.2013.817544

HLW Schrödinger - Höhere Bundeslehranstalt für wirtschaftliche Berufe (2014): Steig ein - red' mit! Zum Beispiel Kunsthaus. Survey. Graz (unpublished).

Jasmand, S.; Maennig, W. (2008): Regional Income and Employment Effects of the 1972 Munich Summer Olympic Games. In: Regional Studies 42, 7, 991-1002. doi: 10.1080/00343400701654095

Jencks, C. (2004): The Truth About Icons. In: The Architects' Journal. 9 September 2004. https://www.architectsjournal. co.uk/home/the-truth-about-icons/139749.article (04.09.2020).

Jencks, C. (2006): The iconic building is here to stay. In: City 10, 1 , 3-20. doi: 10.1080/13604810600594605

Jencks, C. (2011): The Story of Post-Modernism: Five Decades of the Ironic, Iconic and Critical in Architecture. Chichester.

Julian, D.A. (1997): The Utilization of the Logic Model as a System Level Planning and Evaluation Device. In: Evaluation and Program Planning 20, 3, 251-257. doi: 10.1016/S01497189(97)00002-5

Klingmann, A. (2007): Beyond Bilbao. Brandscapes: Architecture in the Experience Economy. Boston.

Klute, H. (2003): Graz feiert sich als Europäische Kulturhauptstadt 2003. Flucht aus Pensionopolis. In: Süddeutsche Zeitung vom 8. April 2003, V2/1.

Krauss, G. (2015): The Creation of a Second Centre Pompidou in Metz: Social Embedding of a New Regional Cultural Facility and Formation of a Strategic Action Field. In: European Planning Studies 23, 8, 1494-1510. doi: 10.1080/09654313.2013.817542

Kubinzky, K.A. (2009): Die Murvorstadt: Lend und Gries. Die Geschichte zweier Grazer Stadtbezirke von der Mitte des 19.
Jahrhunderts bis in die Gegenwart. In: Murlasits, E.; Prasenc, G.; Reisinger, N. (eds.): Gries. Lend. Geschichten, Räume, Identitäten. Graz, 19-24

Landesrechnungshof Steiermark (2008): Landesmuseum Joanneum GmbH. Berichtzahl LRH 20 J 3/2008-55. Graz.

Lazzeretti, L.; Capone, F. (2015): Museums as Societal Engine for Urban Renewal. The Event Strategy of the Museum of Natural History in Florence. In: European Planning Studies 23, 8, 1548-1567. doi: 10.1080/09654313.2013.819073

Leitner, E. (2012): Stadtbaukultur durch Kulturhauptstadt. Zur Rolle stadträumlicher und baukultureller Aspekte im Rahmen der Initiative Kulturhauptstadt Europas. Dissertation, Technische Universität Wien.

McLaughlin, J.A.; Jordan, G.B. (1999): Logic Models: A Tool for Telling Your Program's Performance Story. In: Evaluation and Program Planning 22, 1, 65-72. doi: 10.1016/S01497189(98)00042-1

Musgrave, R.A.; Musgrave, P.B.; Kullmer, L. (1977): Die öffentlichen Finanzen in Theorie und Praxis. Tübingen.

Musgrave, R.A. (1987): Merit Goods. In: Eatwell, J.; Milgate, M.; Newman, P. (eds.): The New Palgrave. A Dictionary of Economics. London, 451-453.

Ockman, J.; Frausto, S. (eds.) (2005): Architourism: authentic, escapist, exotic, spectacular. München.

Passegger, N. (2006): Imageanalyse und kommunikationspolitische Auswirkungen Kunsthaus Graz. Survey. Graz (unpublishd).

Patterson, M. (2012): The Role of the Public Institution in Iconic Architectural Development. In: Urban Studies 49, 15, 32893305. doi: 10.1177/0042098012443862

Plaza, B. (2000): Evaluating the influence of a large cultural artifact in the attraction of tourism. The Guggenheim Museum Bilbao case. In: Urban Affairs Review 36, 2, 264-274. doi: 10.1177/10780870022184859

Plaza, B. (2006): The Return on Investment of the Guggenheim Museum Bilbao. In: International Journal of Urban and Regional Research 30, 2, 452-467. doi: 10.1111/j.14682427.2006.00672.x

Plaza, B. (2008): On Some Challenges and Conditions for the Guggenheim Museum Bilbao to be an Effective Economic Re-activator. In: International Journal of Urban and Regional Research 32, 2, 506-517. doi: 10.1111/j.1468-2427.2008.00796.x

Plaza, B. (2013): Der „Bilbao-Effekt“. In: Wang, W. (ed.): Kultur: Stadt. Berlin, 62-65.

Plaza, B.; Gonzáles-Casimiro, P.; Moral-Zuazo, P.; Waldron, C. (2015): Culture-led city brands as economic engines: theory and empirics. In: Annals of Regional Sciences 54, 1, 179-196. doi: 10.1007/s00168-014-0650-0

Plaza, B.; Haarich, S.N. (2015): The Guggenheim Museum Bilbao: Between Regional Embeddedness and Global Networking. In: European Planning Studies 23, 8, 1456-1475. doi: 10.1080/09654313.2013.817543

Plaza, B.; Tironi, M.; Haarich, S.N. (2009): Bilbao's Art Scene and the "Guggenheim effect" Revisited. In: European Planning Studies 17, 11, 1711-1729. doi: 10.1080/09654310903230806

Ponzini, D. (2011): Large scale development projects and star architecture in the absence of democratic politics: The case of Abu Dhabi, UAE. In: Cities 28, 3, 251-259. doi: 10.1016/j. cities.2011.02.002

Ponzini, D.; Nastasi, M. (2016): Starchitecture. Scenes, Actors and Spectacles in Contemporary Cities. New York. 
Rius-Ulldemolins, J.; Hernandez Marti, G.M.; Torres, F. (2015): Urban Development and Cultural Policy "White Elephants": Barcelona and Valencia. In: European Planning Studies 24, 1, 61-75. doi: 10.1080/09654313.2015.1075965

Rodríguez, A.; Martínez, E.; Guenaga, G. (2001): Uneven Redevelopment. New Urban Policies and SocioSpatial Fragmentation in Metropolitan Bilbao. In: European Urban and Regional Studies 8, 2, 161-178. doi: 10.1177/096977640100800206

Scherer, R. (2002): Die räumliche Inzidenz des Lucerne Festivals. In: Informationen zur Raumentwicklung 4/5, 271-275.

Scherer, R.; Strauf, S.; Riser, A.; Gutjahr, M. (2012): Regionalwirtschaftliche Bedeutung des Kultur- und Kongresszentrums Luzern. St. Gallen.

Schneider, S. (2012): Blob-Architektur für das 21. Jahrhundert. Neues Paradigma oder Relaunch einer ehrwürdigen Tradition? Marburg.

Sedlmeier, F. (2016): Das Kunsthaus Graz und seine Wirkungskraft. Eine Gewerbeanalyse. Student work at the Chair of Urban Development, Technical University of Munich (unpublished).

Sklair, L. (2006): Iconic architecture and capitalist globalization. In: City 10, 1, 21-47. doi: 10.1080/13604810600594613

Smith, A.; von Krogh Strand, I. (2011): Oslo's new Opera House: Cultural flagship, regeneration tool or destination icon? In: European Urban and Regional Studies 18, 1, 93-110. doi: 10.1177/0969776410382595

Smith, T. (2008): Spectacle Architecture before and after the Aftermath: Situating the Sydney Experience. In: Vidler, A. (ed.): Architecture between spectacle and use. Williamstown, 3-24.

Thierstein, A.; Alaily-Mattar, N.; Dreher, J. (2020): Star architecture's interplays and effects on cities. In: Alaily-Mattar, N.; Ponzini, D.; Thierstein, A. (eds.): About Star Architecture. Cham, 45-54.

Vicario, L.; Martínez Monje, P.M. (2003): Another 'Guggenheim Effect'? The Generation of a Potentially Gentrifiable Neighbourhood in Bilbao. In: Urban Studies 40, 12, 23832400. doi: $10.1080 / 0042098032000136129$

Weidenfeld, A. (2010): Iconicity and flagshipness of tourist attractions. In: Annals of Tourism Research 37, 3, 851-854. doi: 10.1016/j.annals.2010.02.007

Weiss, C.H. (1997): How Can Theory-Based Evaluation Make Greater Headway? In: Evaluation Review 21, 4, 501-524. doi: 10.1177/0193841X9702100405

Zakarias, G.; Gertzmacher, N.; Gruber, M.; Kurzmann, R.; Steiner, M.; Streicher, G. (2002): Kunst und Wirtschaft Graz 2003. Kulturhauptstadt Europas. Eine Analyse der wirtschaftlichen Auswirkungen. Graz. = InTeReg Research Report 04-2002.

Zimmermann, H.; Henke, K.D. (2001): Finanzwissenschaft. München. 